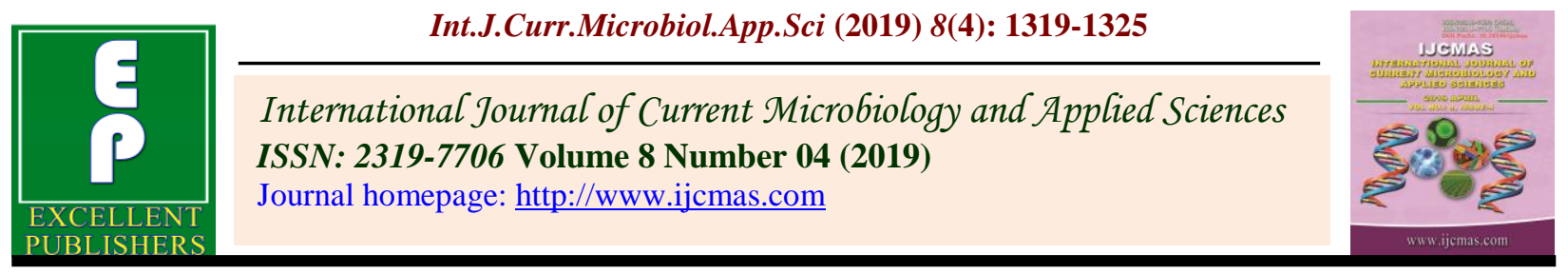

Original Research Article

https://doi.org/10.20546/ijcmas.2019.804.153

\title{
Screening of Heavy Metal (Lead) and Antibiotics Resistant Soil Bacteria from Myanmar Industrial Sites
}

\author{
May Sandar Kyaing*, Myat Thin Khaing and Khin Maung Saing \\ Biotechnology Research Department, Kyauk-se District, Myanmar \\ *Corresponding author
}

\begin{tabular}{|c|c|}
\hline & A B S T R A C T \\
\hline & \multirow{4}{*}{$\begin{array}{l}\text { Heavy metals are hazardous to living things and causes deterioration of the environment. } \\
\text { Nowadays, contamination of heavy metals in the soil and water has gradually increased by } \\
\text { human activities. This study analyzed soils from two industrial sites in Myanmar and lead } \\
\text { tolerant soil bacteria, E.coil and Alcaligenes sp. were isolated, and characterized. MIC } \\
\text { value of lead for Alcaligenes sp. was } 13 \mathrm{mM} \text { and for E. coil isolates was } 10 \mathrm{mM} \text {, } \\
\text { respectively. Those isolates could tolerate fixed concentrations of three antibiotics (each } \\
50 \mathrm{ug} / \mathrm{ml} \text { of Chloramphenicol, Kanamycin, Tetracycline) together with } 5 \mathrm{mM} \text { of } \mathrm{Pb}\left(\mathrm{NO}_{3}\right)_{2} \\
\text { and co-existence of both lead tolerance and antibiotic resistance were found. This research } \\
\text { might somehow provide information for heavy metal and antibiotic resistant bacteria and } \\
\text { those isolates would be good indicators for further bioremediation processes. }\end{array}$} \\
\hline $\begin{array}{l}\text { Heavy Metal, Lead, } \\
\text { Antibiotics } \\
\text { Resistant, } \\
\text { Soil Bacteria }\end{array}$ & \\
\hline Article Info & \\
\hline $\begin{array}{l}\text { Accepted: } \\
\text { 12 March } 2019 \\
\text { Available Online: } \\
10 \text { April } 2019\end{array}$ & \\
\hline
\end{tabular}

\section{Introduction}

Although heavy metals are natural elements present in the environment, accumulation of these elements to higher amounts are hazardous to living things and causes deterioration of the environment. Nowadays, contamination of heavy metals in the soil and water have gradually increased by human activities such as mining and smelting of metals, burning of fossil fuels, use of fertilizers and pesticides in agriculture practices, production of batteries and other metal products in industries, automobile emission, sewage sludge, and municipal waste disposal. While some heavy metals such as zinc, copper, chromium, iron, and manganese are needed in small amount for our bodies, lead, mercury, arsenic, and cadmium are the most toxic heavy metals and these poisoning can cause serious damage to our body's tissues.

Yang QQ et al., (2018) surveyed soil heavy metal pollution in 402 industrial and 1041 agricultural sites throughout China and it was found that heavy metal pollution and their associated risks posed by cadmium (Cd), lead $(\mathrm{Pb})$ and arsenic (As) are more serious even at very low concentrations than other heavy metals in industrial and agricultural regions in China. Pollution of soil contaminated by heavy metals can cause losses in microbial diversity and decreases the activity of 
microorganisms. Soil microbial biomass was an important indicator for determination of excess soil contamination (Aceves et al., 1999). Different responses of microbial population to heavy metals depend on multiple factors such as different types of heavy metals and their concentration, and tolerance on microbial species (Valls and De Lorenzo 2002). Some bacteria possess the ability to survive in the heavy metal contaminated are a sand such bacteria tolerant to specific metals might be potentially useful in bioremediation processes.

Lead is a major pollutant found in the atmosphere and is greatly toxic to human, animals, plants and environments. Lead has been widely used in batteries production, antiknock agent in gasoline, reaction tank, soldering, wire and cable insulation and jacking, radiation shields, ammunitions, stiffener in candle wicks and paint factories for many years (Zhang et al., 2015). Lead pollution can cause severe effects in soil and water ecosystems such as losses in biodiversity, changes in microbial community as well as decreased pollen germination and seed viability, reduced growth and reproductive rates in plants and animals (Krishnayya and Bedi, 1986; Myra et al., 2012).

In human, severe effects were caused by lead pollution to the children more than the adults and in 2016, 540,000 people were died due to lead contamination (WHO, 2016). Pollution of heavy metal becomes to threaten human life, and environment worldwide year by year. In Myanmar, as more and more industrial zones are developed nowadays and agricultural lands are contaminated with the uses of fertilizers and pesticides than before, it is needed to control pollution of heavy metals by use of remediation processes such as electrokinetic remediation, soil leaching, phytoremediation and microbial remediation.
The objective of this study is to investigate the soil analysis from two industrial sites, to identify lead tolerant bacteria and evaluate their minimum inhibitory concentrations of lead. This research may somehow benefit for further identification of heavy metals tolerant soil bacteria and microbial remediation processes.

\section{Materials and Methods}

\section{Soil Sample collection}

Soil samples were collected from two places situated near Yangon; (1) Defense Service Paint Factory (DSPF), (2) Myanmar Automobile and Diesel Engine Industries (MADI). The soil samples $(0-15 \mathrm{~cm}$ depth) were collected from each site into freshly unused polythene bags and were taken to the laboratory.

\section{Screening, characterization and identification of lead tolerant bacteria}

One $\mathrm{ml}$ of $10^{-5}$ dilution of soil suspension was plated out onto freshly prepared sterile nutrient agar medium containing $10 \mathrm{mg} / \mathrm{l}$ of $\mathrm{Pb}\left(\mathrm{NO}_{3}\right)_{2}$. After incubation for $24-48 \mathrm{hrs}$ at $37^{0} \mathrm{C}$, mucous colonies were formed over the plate and streaking plate method was used to get single colonies of pure culture. Resistant single colonies were characterized by colony morphology, staining and biochemical tests. Biochemical screening was done according to Bergey's Manual of Systematic Bacteriology (Bergey et al., 1984). Biochemical tests such as IMViC (Indole, Methyl red, VP, TSI and citrate) and were performed to evaluate the enzymatic activity of isolated microorganisms.

\section{Evaluation of lead tolerance level and antibiotics}

The tolerance of bacterial isolates to lead was determined by Minimum Inhibitory 
Concentration (MIC). One loop of bacterial culture was streaked on selective agar plates containing different concentrations of $\mathrm{Pb}$ $\left(\mathrm{NO}_{3}\right)_{2}(1 \mathrm{mM}, 3 \mathrm{mM}, 5 \mathrm{mM}, 7 \mathrm{mM}, 10 \mathrm{mM}, 11$ $\mathrm{mM}, 12 \mathrm{mM}, 13 \mathrm{mMand} 14 \mathrm{mM}$ ) of lead (II) nitrate until the isolate enabled to give colonies. The MICs value was determined after 48 hours of incubation at $37^{\circ} \mathrm{C}$ (Rajbanshi, 2008).

Double screening with $\mathrm{Pb} \quad\left(\mathrm{NO}_{3}\right)_{2}$ and antibiotics was performed together and fixed concentrations of each antibiotic $((50 \mu \mathrm{g} / \mathrm{ml}$ of Chloramphenicol, Kanamycin, Tetracycline) were used.

\section{Results and Discussion}

In this study, soil analysis test were performed by digestion method at soil analysis laboratory, Ministry of Science and Technology Research Department (MSTRD), Yangon. The result showed that soil samples from DSPF contained lead $(\mathrm{Pb})$ at $0.01 \%$ (100 ppm) and Copper (Cu) at 0.02\% (200 ppm). Similarly, soil samples from MADI contained $0.01 \%(100 \mathrm{ppm})$ of lead $(\mathrm{Pb})$ and $0.02 \%(200 \mathrm{ppm})$ of Copper $(\mathrm{Cu})$ but Arsenic and zinc were not detectable in both industrial sites (Table 1). Lead is considered as hazardous element and maximal permissible addition (MPA) value for lead is 55 ppm (55 $\mathrm{mg} / \mathrm{kg}$ ) (Vodyanitskii et al., 2016). Therefore, it was concluded that industrial sites in Myanmar were starting to be contaminated with lead and it is needed to regard as a major concerning issue for controlling contamination of heavy metals. Further examinations are needed to carry out in other industrial zones which might also be contaminated with heavy metals and the cleanup strategy are necessary to apply for eliminating the pollution.

This soil analysis results allowed to be focused on bacteria tolerant to lead and copper and the present study only carried out to isolate and characterize lead tolerant bacteria. According to morphological and microscopic morphology (Table 2 and Table 3), rod-shaped gram-negative bacteria were found in two collected sample sites. When basic biochemical characteristics such as MR, VP, Citrate, Indole, TSI tests were used to identify the isolates, we can characterize that the bacteria found in these collected soil samples were E. coil and Alcaligene sp (Table 3 and Figure 1-2). Several previous studies also indicated that lead resistance in many indigenous microorganisms including Bacillus sp., Pseudomonas sp., Acinetobacter sp., Flavobacterium sp., Escherichia coli and Alcaligenes sp. have been identified from the lead contaminated soil (Trajanovska $\mathrm{S}$ et al., 1997; Tamil Selviet et al., 2012).

For evaluation of tolerant level to lead (II) nitrate, it was found that Minimum Inhibitory Concentrations (MIC) of Alcaligenes isolate was $13 \mathrm{mMand}$ that of E.coli isolate was 10 $\mathrm{mM}$ revealing these isolates were designated to be used as good candidates for further bioremediation research. Similarly, the MIC of lead was found to be $60-80$ ppm for E.coil and and MIC for Alcaligenes sp. was $80 \mathrm{ppm}$ (Tamil Selvit et al., 2012) and it seemed Alcaligene ssp might have possibility to tolerate heavy metals than E.coli. Irawati et al., (2017) identified indigenous heavy metal tolerant bacteria from the industrial sewage and the highest lead tolerant bacteria showed MIC value of $11 \mathrm{mM}$ showing those isolates were used for further study of lead contamination control. Microorganisms can interact with heavy metal via many mechanisms and different level of lead tolerant level might be due to different types of mechanisms such as bioaccumulation and biosorption processes within each isolates (Table 4).

In recent studies, co-existence of both heavy metal tolerance and antibiotic resistance was observed in a number of bacteria and that two 
/more co-resistance genes could be frequently found on mobile elements such as plasmids and transposons as well as also on chromosome. Therefore, double screening method for checking linkage of these heavy metal and antibiotic resistant genes were tested by using fixed concentrations of three antibiotics (Chloramphenicol, Tetracycline, and Kanamycin) together with $5 \mathrm{mM}, 7 \mathrm{mM}$ and $10 \mathrm{mM}$ lead (II) nitrate in selective media. It was observed that both Alcaligenes sp and E.coil isolates showed resistance to each 50 $\mathrm{ug} / \mathrm{ml}$ of three kinds of antibiotics but MIC level of lead tolerance was reduced to $5 \mathrm{mM}$ lead (II) nitrate. It was possible that these wild type isolates were not adapted to more than 5
$\mathrm{mM}$ lead (II) nitrate compound at fixed concentrations of three antibiotics. Although the cell was struggling against two stresses at the same time, by carrying both genes for heavy metal (lead) and antibiotic resistances, it was regarded that these isolates contained both heavy metal and drug resistant genes and somehow, soil from two industrial sites were contaminated with both heavy metals and antibiotics. In many natural environments, the emergence of metal resistance and multidrug resistance in bacteria has been observed due to co-contaminations of heavy metal and antibiotics (Chen et al., 2015) and it might be a major issue for controlling pollution and infectious diseases (Table 5).

Table.1 Soil sample analysis of heavy metals by digestion method

\begin{tabular}{|l|l|l|l|l|}
\hline Places & Lead & Copper & Arsenic & Zinc \\
\hline DSPF & $0.01 \%(100 \mathrm{ppm})$ & $0.02 \%(200 \mathrm{ppm})$ & ND & ND \\
\hline MADI & $0.01 \%(100 \mathrm{ppm})$ & $0.02 \%(200 \mathrm{ppm})$ & ND & ND \\
\hline
\end{tabular}

DSPF $=$ Defense Service Paint Factory

MAID=Myanmar automobile and Diesel Engine Industries

$\mathrm{ND}=$ Non-detected

Table.2 Study of colony morphology and microscopic morphology

\begin{tabular}{|c|c|c|}
\hline $\begin{array}{l}\text { Morphological } \\
\text { characters }\end{array}$ & E.coli isolates & Alcaligenes sp isolates \\
\hline $\begin{array}{l}\text { Colony Morphology } \\
\text { Color } \\
\text { Shape } \\
\text { Surface } \\
\text { Elevation } \\
\text { Edge } \\
\text { Opacity } \\
\text { Gram-stain } \\
\text { Microscopic } \\
\text { Morphology } \\
\text {-Cell size } \\
\text {-Shape } \\
\text {-Motility }\end{array}$ & $\begin{array}{l}\text {-Pink colony on MacConkey agar } \\
\text {-Circular } \\
\text {-Smooth } \\
\text {-Flat } \\
\text {-Entire } \\
\text {-Translucent } \\
\text {-Negative } \\
-0.6 \mu \mathrm{m}-2-6 \mu \mathrm{m} \\
\text {-Single rods, coccal rods } \\
-+\end{array}$ & $\begin{array}{l}-0.5-1.2 \mu \mathrm{m}-0.5-2.6 \mu \mathrm{m} \\
- \text { Rods, single, in pairs or in } \\
\text { short chains } \\
-+\end{array}$ \\
\hline
\end{tabular}


Table.3 Biochemical tests of two isolates

\begin{tabular}{|l|c|c|}
\hline Biochemical characteristics & E. coli isolates & Alcaligenes isolates \\
\hline TSI & - & + \\
Indole & - & + \\
MR & - & + \\
VP & - & - \\
Citrate & + & - \\
Catalase & + & + \\
Growth on Mac Conkey agar & + & + \\
Growth at 42 ${ }^{\mathbf{C}}$ & - & + \\
Aerobic & + & + \\
Gelatin liquifaction & + & + \\
\hline
\end{tabular}

Table.4 Evaluation of Minimum Inhibitory Concentration (MIC) to Lead (II) Nitrate without antibiotics

\begin{tabular}{|l|c|c|}
\hline $\begin{array}{l}\text { Concentrations } \\
\text { of } \mathrm{Pb}\left(\mathrm{NO}_{3}\right)_{2}\end{array}$ & E. coli isolates & Alcaligenes isolates \\
\hline $1 \mathrm{mM}$ & + & + \\
$\mathbf{3 m M}$ & + & + \\
$\mathbf{5 m M}$ & + & + \\
$7 \mathrm{mM}$ & + & + \\
$10 \mathrm{mM}$ & + & + \\
$11 \mathrm{mM}$ & + & + \\
$12 \mathrm{mM}$ & - & + \\
$13 \mathrm{mM}$ & - & + \\
$14 \mathrm{mM}$ & - & - \\
\hline
\end{tabular}

Table.5 Double Screening of two isolates with $\mathrm{Pb}\left(\mathrm{NO}_{3}\right)_{2}$ and three antibiotics

\begin{tabular}{|l|c|c|c|}
\hline $\begin{array}{l}\text { Concentrations of } \\
\mathbf{P b}\left(\mathbf{N O}_{\mathbf{3}}\right)_{\mathbf{2}}\end{array}$ & $\begin{array}{l}\text { Concentrations of } \\
\text { three antibiotics }\end{array}$ & E.coli isolates & Alcaligenes isolates \\
\hline $\mathbf{5 m M}$ & $50 \mathrm{ug} / \mathrm{ml}$ each & + & + \\
\hline $\mathbf{7 m M}$ & $50 \mathrm{ug} / \mathrm{ml}$ each & - & - \\
\hline $\mathbf{1 0 m M}$ & $50 \mathrm{ug} / \mathrm{ml} \mathrm{each}$ & - & - \\
\hline
\end{tabular}

Three antibiotics (Chloramphenicol, Kanamycin, Tetracycline) 
Fig.1 (a) IMViC test of Alcaligenes sp isolate (b) IMViC test of E.coli isolate

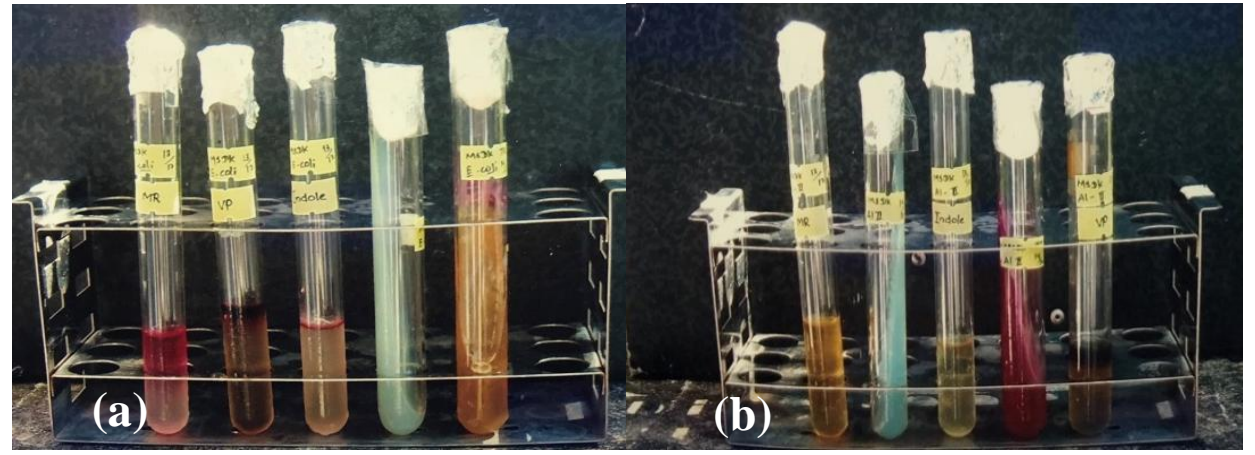

Fig.2 (a) Pure culture of E.coli on Mac Conkey agar medium (b) Pure culture of Alcaligenes sp. on selective agar medium

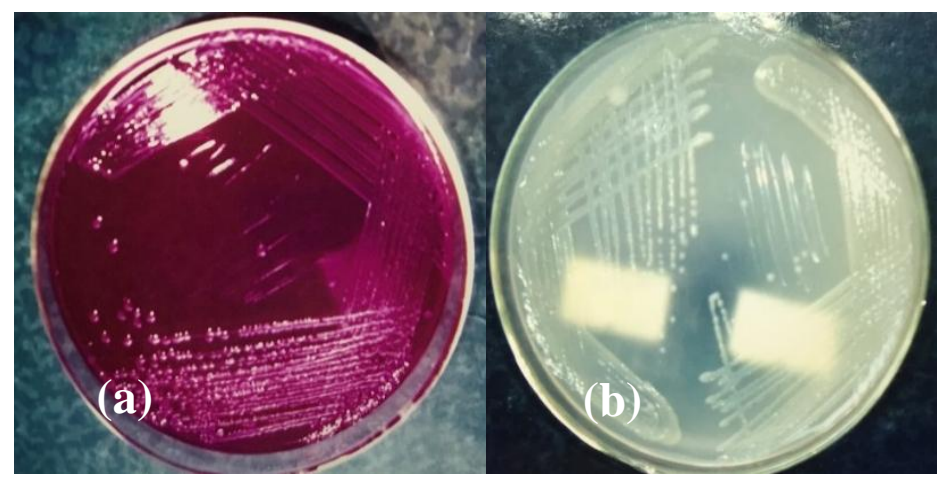

As it was obviously found the co-existence of heavy metal resistant genes and antibiotic resistant genes together in the collected isolates, these two genes might be located either on the same chromosome or on the same plasmid. When further study was done by extracting the plasmid DNA from these double screening isolates, it was observed that colonies of wild types $E$. coli isolate possessed approximately $2.3 \mathrm{~kb}$ of plasmids in size whereas wild type Alcaligenes sp. had large plasmids about $23 \mathrm{~kb}$ in size (Data not shown). Therefore, it can conclude that heavy metal resistant genes and antibiotic resistant genes were together on mobile genetic elements, plasmids and plasmids aid the bacteria for tolerance and resistance mechanisms against heavy metals and antibiotics in the pollutant environment. In conclusion, this study indicated that bacteria with lead tolerant and three kinds of antibiotic resistance were observed in soils from two industrial sites. Contaminated sites are sources for microorganisms with heavy metal tolerant activities and the bacterium which is multiple tolerant to many heavy metals can be effectively used as a biosorbent in the pollutant area with more than one type of heavy metals (Irawati et al., 2017). Therefore, these isolates would be good indicators for bioremediation processes and further analysis of those lead tolerant isolates with other hazardous heavy metals should be also examined.

\section{References}

Aceves, MB, Grace C, Ansorena J, et al., 1999 Soil microbial biomass and organic $\mathrm{C}$ in a gradient of zinc concentration in soils 
around a mine spoil tip. Soil Biology and Biochemisty, 31(6): 867-876

Ananthanarayan, R.; Panicker, J.K. 2005 [1978]. Ananthanarayan and Panicker's Textbook of Microbiology (7 ed.). Orient BlackSwan. ISBN 81-250-2808-0.

Bergey, D. H., Noel R. Krieg, and John G. Holt 1984 Bergey's manual of systematic bacteriology. Baltimore, MD: Williams \& Wilkins.

Chen, S, Li X, Sun G, et al., 2015 Heavy metal induced antibiotic resistance in bacterium LSJC7. International Journal of Molecular Science. 16(10):23390-23404

Chibuike, GU and Obiora SC 2014 Heavy Metal Polluted Soils: Effect on Plants and Bioremediation Methods Applied and Environmental Soil Science ID 752708 https://doi.org/10.1155/2014/752708

Irawati, W, Riak S, Sopiah N, Sulistia S 2017 Heavy metal tolerance in indigenous bacteria isolated from the industrial sewage in Kemisan River Tangerang, Banten, Indonesia. Biodiversitas 18 (4) 1481-1486

Krishnayya, NSR, Bedi SJ. 1986 Effect of automobile lead pollution on Cassia tora L. and Cassia occidentalis L. Environmental Pollution Series A, Ecological and Biological. 40(3), 221226.

Myra, EF, Daniel FD, Daniel G, Joe B, Joseph B, Molly C, Jesse G, Donald R.S. 2012 Lead poisoning and the deceptive recovery of the critically endangered California condor Proc Natl AcadSci USA 109(28), 11449-54.

Qianqi Yang, Zhiyuan Li, Xiaoning Lu, Qiannan Duan, Lei Huang, Jun Bi 2018 A review of soil heavy metal pollution from industrial and agricultural regions in China: Pollution and risk assessment. Science of the Total Environment: 642, P 690-700

Rajbanshi, A 2008 Study on heavy metal resistant bacteria in Guheswori sewage treatment plant. Our Nature 6 (1): 52-57.

Rui Zhang, Vincent L. Wilson, AixinHou, Ge Meng 2015 Source of lead pollution, its influence on public health and the countermeasures. International Journal of Health, Animal science and Food safety 2: $18-31$

Tamil Selvi, A, Anjugam E, Archana Devi R, Madhan B, Kannappan S and Chandrasekaran B 2012 Isolation and characterization of bacteria from tannery effluent treatment plant and their tolerance to heavy metals and antibiotics. ASIAN J. EXP. BIOL. SCI. 3 (1): 34 - 41

Trajanovska, S, Britz M L, Bhave M 1997 Detection of heavy metalion resistance genes in gram-positive and gram-negative bacteria isolated from a leadcontaminated site. Biodegradation 8, 113124

Valls, M. and V. De Lorenzo 2002Exploiting the genetic and biochemical capacities of bacteria for the remediation of heavy metal pollution. FEMS Microbiol. Rev., 26: 327-338.

Vodyanitskii, YN, 2016 Standards for the contents of heavy metals in soils of some states. Annals of Agrarian Science 14 (3): 257-263

WHO 2016 Lead poisoning and health

\section{How to cite this article:}

May Sandar Kyaing, Myat Thin Khaing and Khin Maung Saing. 2019. Screening of Heavy Metal (Lead) and Antibiotics Resistant Soil Bacteria from Myanmar Industrial Sites. Int.J.Curr.Microbiol.App.Sci. 8(04): 1319-1325. doi: https://doi.org/10.20546/ijcmas.2019.804.153 